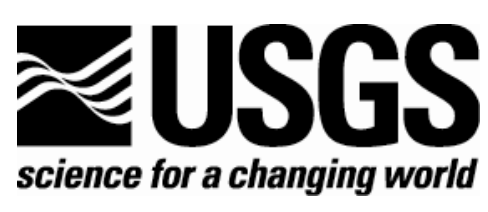

\title{
Evaluation of Oxygen and Carbon Isotopes in sediments from Bear Lake, Utah and Idaho
}

By Jordon Bright and Darrell Kaufman

Open-File Report 2005-1228

U.S. Department of the Interior

U.S. Geological Survey 


\section{U.S. Department of the Interior \\ Gale A. Norton, Secretary}

\section{U.S. Geological Survey \\ Charles G. Groat, Director}

U.S. Geological Survey, Reston, Virginia 2005

For sale by U.S. Geological Survey, Information Services

Box 25286, Denver Federal Center

Denver, CO 80225

For more information about the USGS and its products:

Telephone: 1-888-ASK-USGS

World Wide Web: http://www.usgs.gov/

Any use of trade, product, or firm names in this publication is for descriptive purposes and does not imply endorsement by the U.S. Government.

Although this report is in the public domain, permission must be secured from the individual copyright owners to reproduce any copyrighted material contained within this report.

This report has not been reviewed for stratigraphic nomenclature.

Suggested citation:

Bright, J. and Kaufman, D., 2005, Evaluation of oxygen and carbon isotopes in sediments from Bear Lake, Utah and Idaho: U.S. Geological Survey Open-File Report 2005-1228, 9p.

Prepared by the U.S. Geological Survey in Denver, Colorado (http://climchange.cr.usgs.gov/) 


\title{
Evaluation of Oxygen and Carbon Isotopes in Sediments from Bear Lake, Utah and Idaho
}

\author{
By Jordon Bright and Darrell Kaufman
}

\section{Introduction}

The goal of this preliminary investigation was to evaluate fundamental aspects of oxygen and carbon isotopes in Bear Lake sediment to provide background information for future analyses. Specifically, we analyzed $\delta^{18} \mathrm{O}$ and $\delta^{13} \mathrm{C}$ to test the minimum sample size required for reliable results on ostracode valves and the benefit of centrifuging sediment to isolate certain density/size fractions. We focused on marl and ostracodes from two cores: (1) a surface core collected in 1998 (hereinafter core 9809 ) and (2) core catcher samples from GLAD800 core BL00-1-D (hereinafter core 00-1D). All samples were analyzed on a Finnigan MAT 252 mass spectrometer at the University of Arizona under the guidance of David Dettman. All isotope ratios are reported in standard $\delta$ notation, relative to Vienna Peedee belemnite (VPDB).

\section{Methods}

\section{Ostracode and marl isotopic analysis}

Fifty-seven subsamples were analyzed from seven, 1-cm-thick intervals in core 98-09. Four intervals predate the historical diversion of Bear River into Bear Lake, and three intervals postdate it. Three species of ostracodes (all Candona) plus the enclosing marl were analyzed from all samples. The samples were washed over a $150 \mu \mathrm{m}$ sieve to remove the ostracodes, and the $<150 \mu \mathrm{m}$ fraction was collected and analyzed (the "marl"). Where available, several valves of Candona sp. 1, 2, and 3 (Bright and others, 2005) were picked from each interval and cleaned using a gentle sonication and deionized water rinses. Sample masses were determined at the University of Arizona by David Dettman. Marl samples were analyzed once (except $24.5 \mathrm{~cm}$, which was run twice); ostracodes were analyzed in several subsets. Based on the gas pressures generated, we determined that three valves (Candona) were the minimum optimal sample size for isotope analyses at the University of Arizona laboratory.

\section{Marl pretreatment tests}

Forty-four subsamples were analyzed to determine whether sediment treated by a centrifugation technique developed by the U.S. Geological Survey would produce different, and perhaps more reliable 
results than untreated samples. Two aragonite-rich samples from core 98-09 and two calcite-rich core catcher samples (13cc and 37cc) from core 00-1D were tested. All four samples were washed over a 150 $\mu \mathrm{m}$ sieve to separate the medium to coarse sand fraction, which includes the ostracodes. The $<150 \mu \mathrm{m}$ fractions were collected and separated into untreated and treated splits. The two untreated splits were each dried at $50^{\circ} \mathrm{C}$, powderized, and divided into five subsamples. The two treated samples were centrifuged at low speed for 30, seconds and the supernatent was decanted and centrifuged again at low speed for 30 seconds. This low speed centrifuge/decant process was repeated a total of 3 times. The fourth supernatant then was collected and centrifuged at high speed for 5 minutes. The suspended fraction then was discarded. The remaining sediments were dried at $50^{\circ} \mathrm{C}$, powderized, and divided into five subsamples for isotope analyses. Sample 00-1D-13cc was treated with one extra step. The 5-minute-decanted fraction was centrifuged a second time at high speed for an additional 5 minutes and five subsamples of the settled mud from this second treatment were analyzed as well.

\section{Results and Discussion}

\section{Ostracodes and marl}

The input of Bear River water into Bear Lake ca. 1912 is clearly expressed in the O and C isotopic composition of ostracodes and marl, but the response was not equal among the sample types (fig. 1). $\delta^{18} \mathrm{O}$ in the marl decreased by $>3 \%$ o following the diversion of the Bear River. $\delta^{18} \mathrm{O}$ in Candona sp. 1 and 2 both decreased $\sim 2 \%$, while $\delta^{18} \mathrm{O}$ in Candona sp. 3 decreased by $\sim 1 \%$ over the same interval. Valves of Candona sp. 2 were more isotopically enriched than valves of Candona sp. 1 and 3. Similarly, $\delta^{13} \mathrm{C}$ in the marls decreased roughly $2 \%$ following the diversion of the Bear River, while $\delta^{13} \mathrm{C}$ in Candona sp. 1 and 2 decreased by only $1 \%$ o (fig. 2). Conversely, $\delta^{13} \mathrm{C}$ in Candona sp. 3 increased by $1 \%$ after the diversion. Valves of Candona sp. 1 were considerably more isotopically depleted in ${ }^{13} \mathrm{C}$ than valves of Candona sp. 2 and 3 (fig. 2).

The most likely explanation for the different responses in ostracode and marl isotopes across the Bear River diversion boundary is that older ostracode valves, valves that calcified near or slightly after the Bear River diversion, are being reworked into younger sediment. It also suggests that the most recent sediments do not contain many, if any, ostracode valves that reflect the isotopic composition of modern lake water.

\section{Marl pre-treatment}

For the aragonite-rich sediment (core 98-09, 4-5 $\mathrm{cm}$ and $18-19 \mathrm{~cm}$ ), the $\delta^{18} \mathrm{O}$ was consistently lower (by $\sim 0.08 \%$ ) for the treated (centrifuged) fraction than for the untreated (sieved only) fraction 

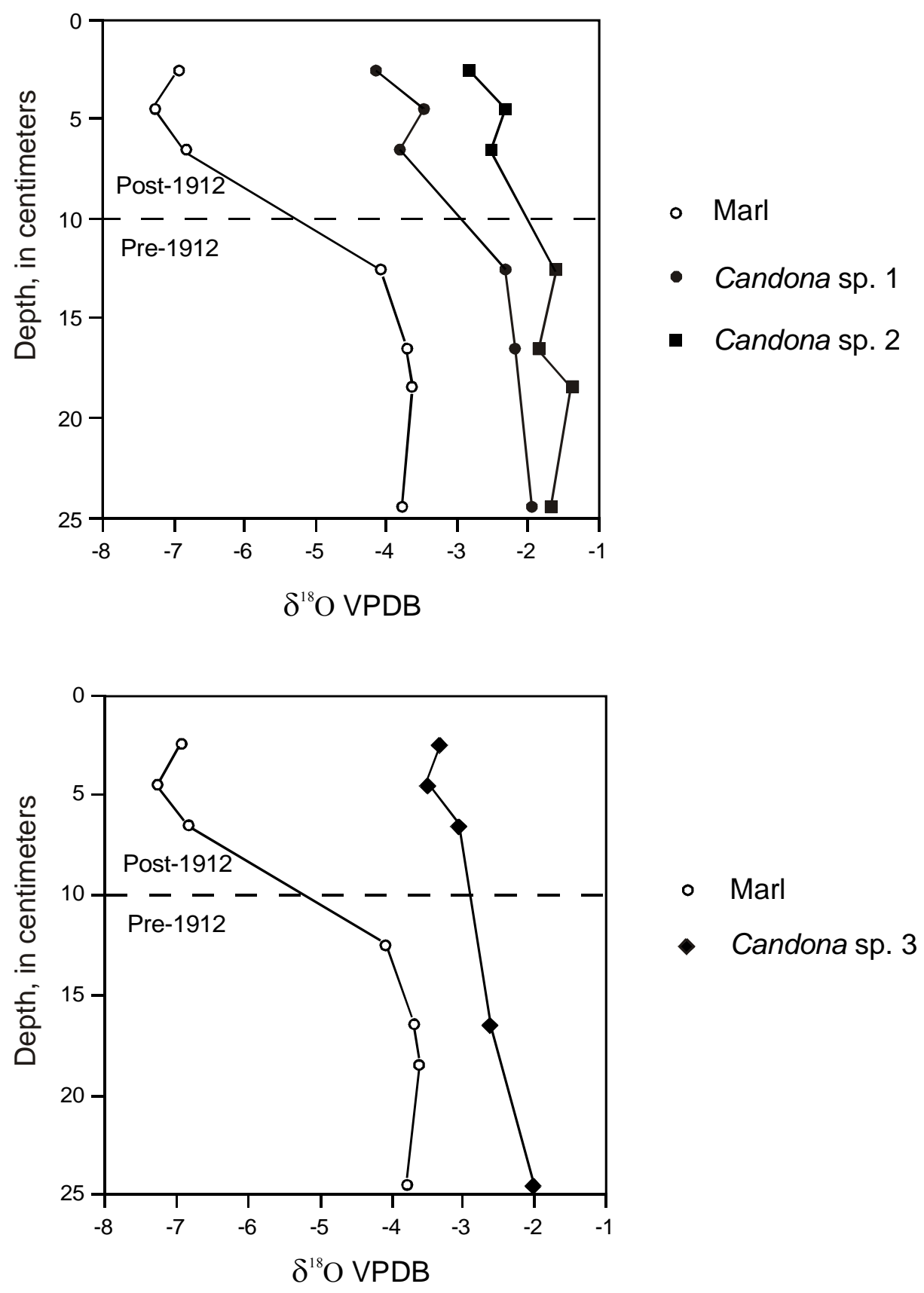

Figure 1. Marl and ostracode isotope response to Bear River diversion ca. 1912, from core 98-09.

(figures 3 and 4). Conversely, $\delta^{13} \mathrm{C}$ in the centrifuged samples was slightly higher (typically by $\sim 0.09 \%$ ) than the untreated samples. Overall, however, the average $\delta^{18} \mathrm{O}$ and $\delta^{13} \mathrm{C}$ of the five subsamples overlapped at $\pm 2 \sigma$ for the treated and untreated subsamples indicating that the variability among the subsamples (sample heterogeneity) was greater than the difference between the treatments.

For the calcite-rich sediment (core 00-1D, $13 \mathrm{cc}$ and $37 \mathrm{cc}$ ), the difference between the treated and untreated samples was more pronounced than for the aragonite-rich sediment (figures 5 and 6 ). 


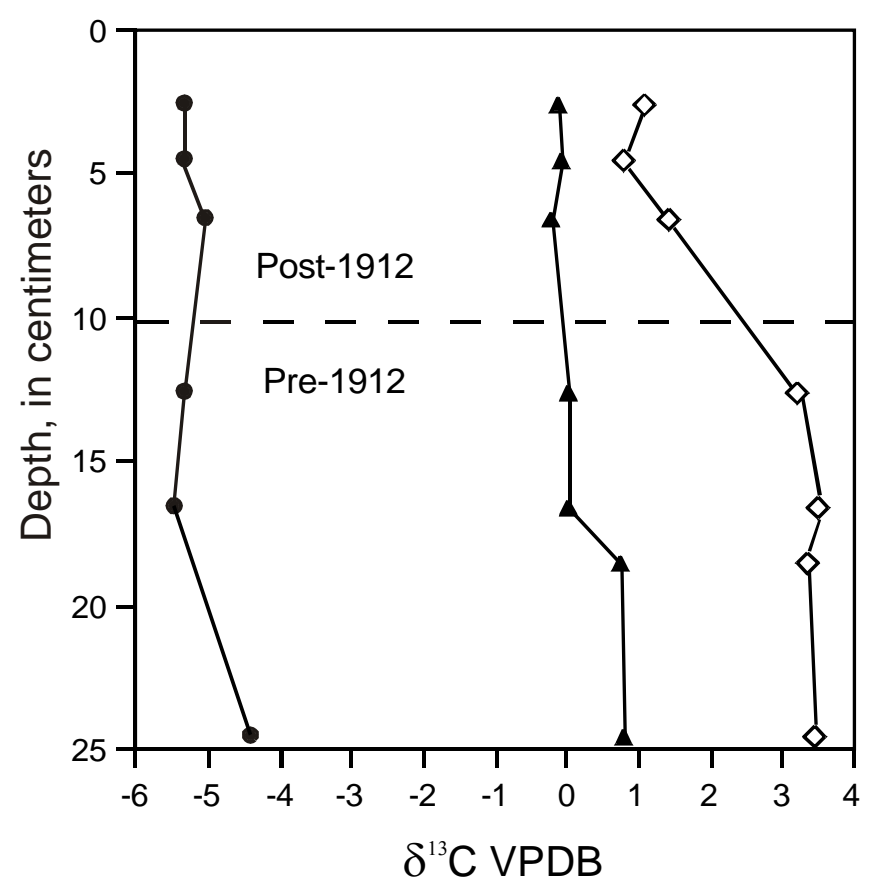

$\diamond$ Marl

- Candona sp. 1

- Candona sp. 2

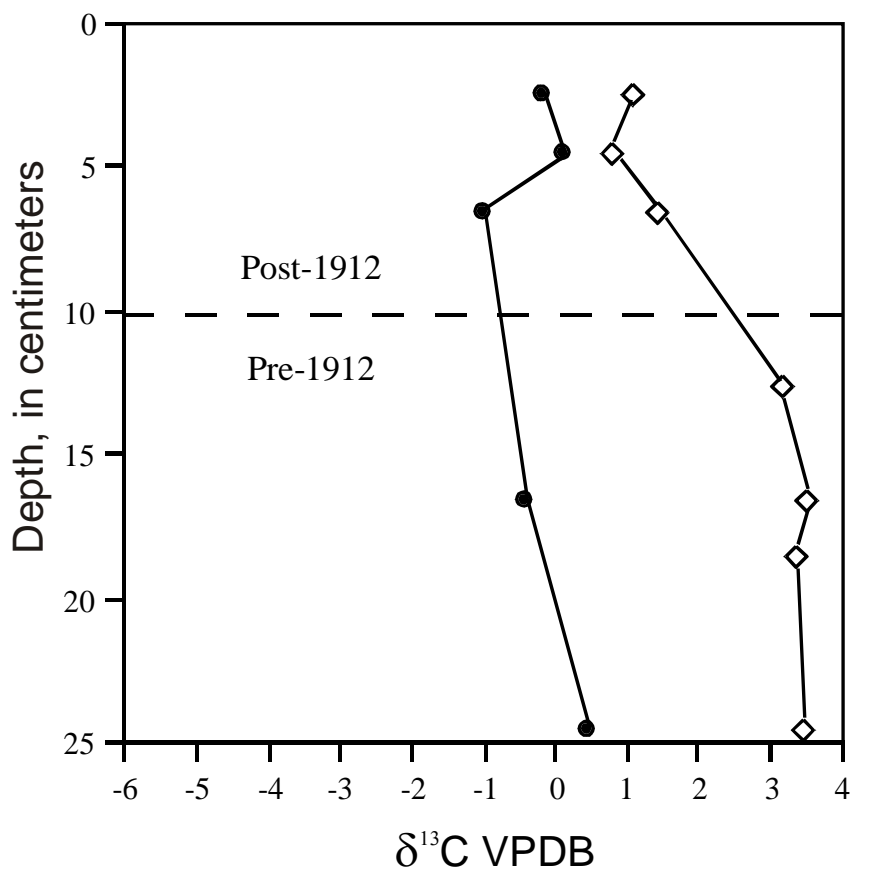

$\diamond \quad$ Marl

- Candona sp. 3

Figure 2. Marl and ostracode carbon isotope response to Bear River diversion ca. 1912, from core 98-09. 


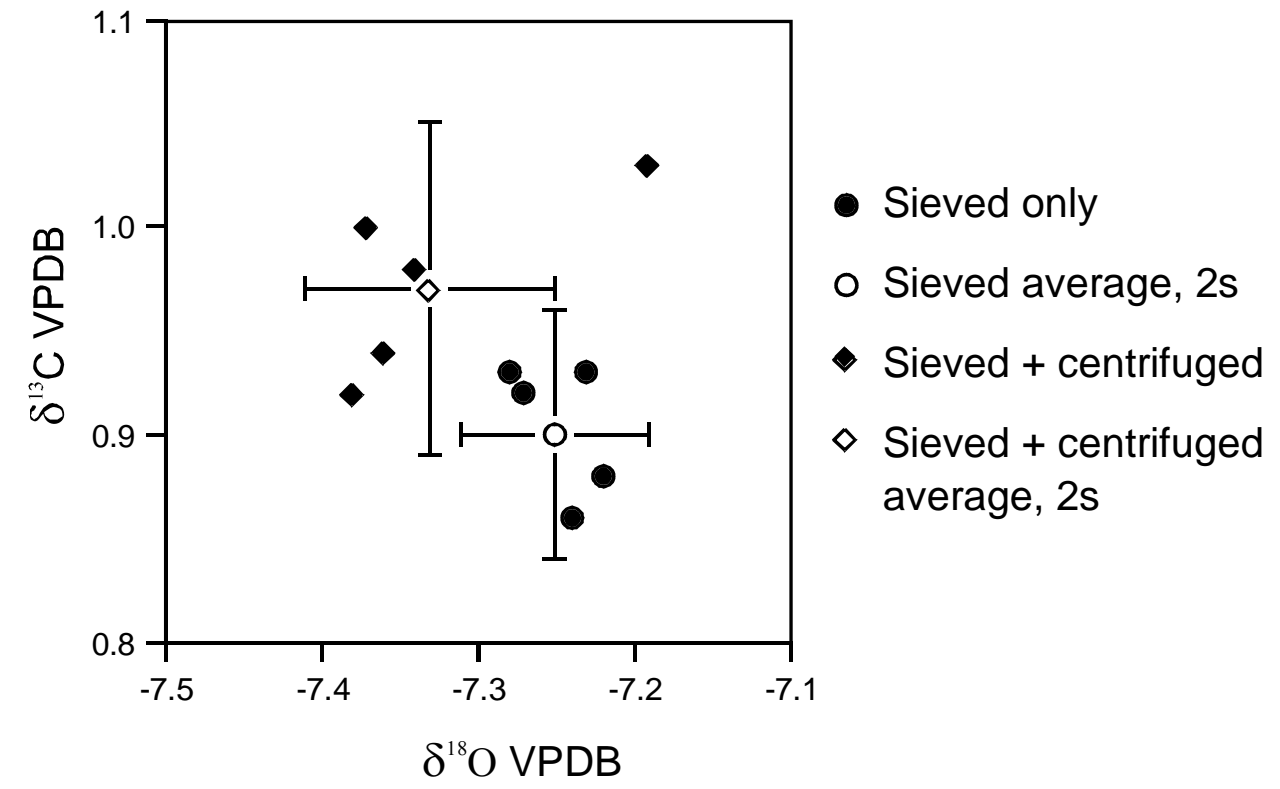

Figure 3. Sieved vs. sieved+centrifuged mud from 98-09, 4-5 cm (40\% aragonite, 13\% low-Mg calcite, 10\% high-Mg calcite).

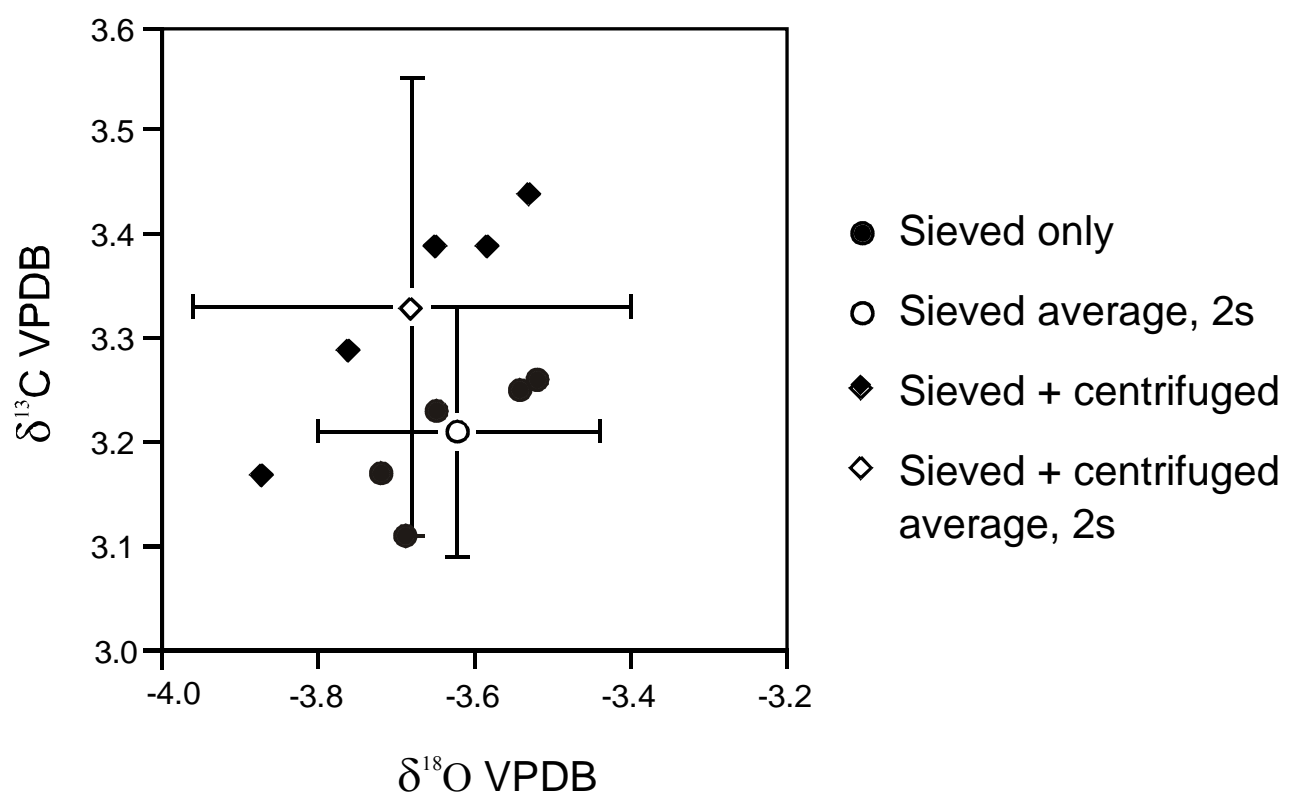

Figure 4. Sieved vs. sieved+centrifuged mud from 98-09, 18-19 cm (50\% aragonite, 14\% low-Mg calcite, 0\% high-Mg calcite). 


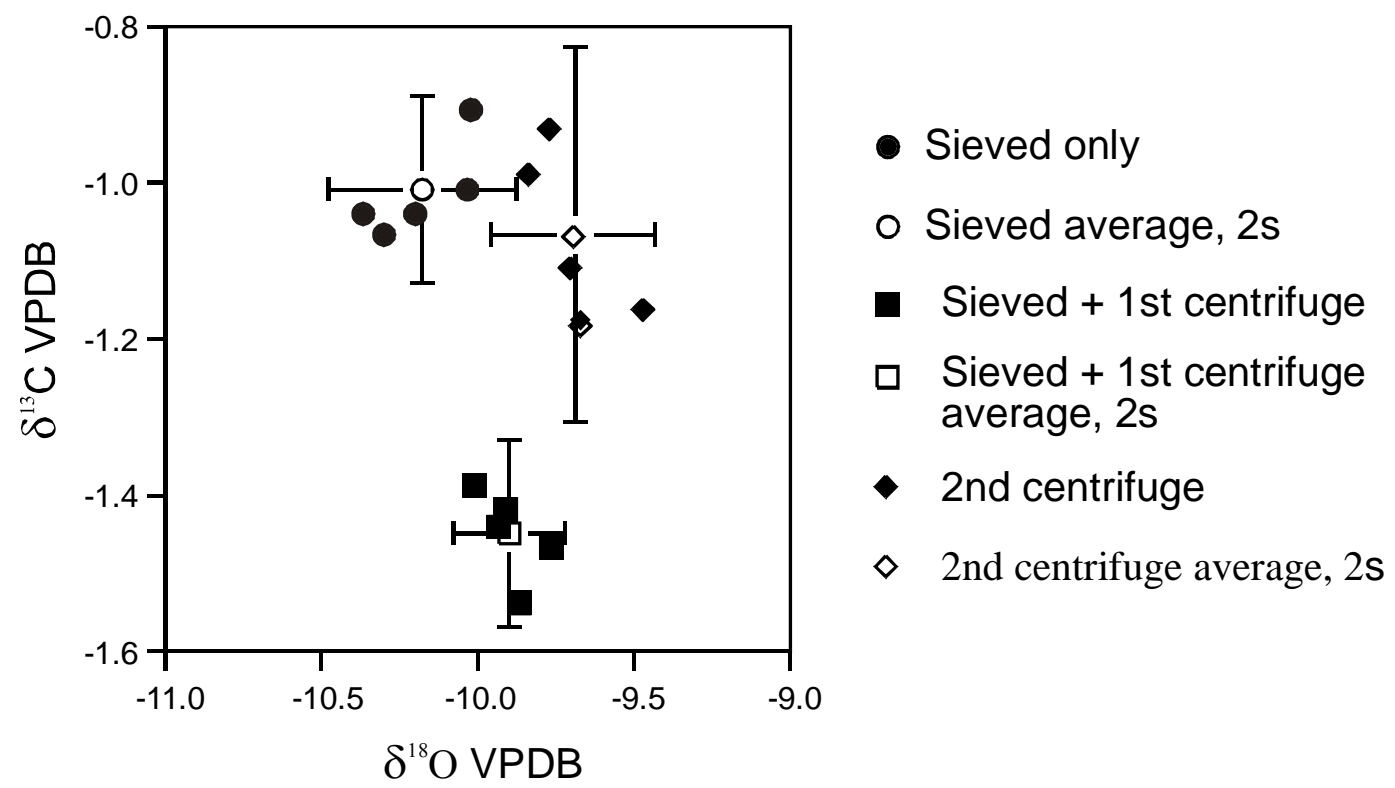

Figure 5. Sieved vs. sieved+centrifuged mud from 00-1D, core catcher 13 (17\% calcite, $62 \%$ quartz, $0 \%$ aragonite).

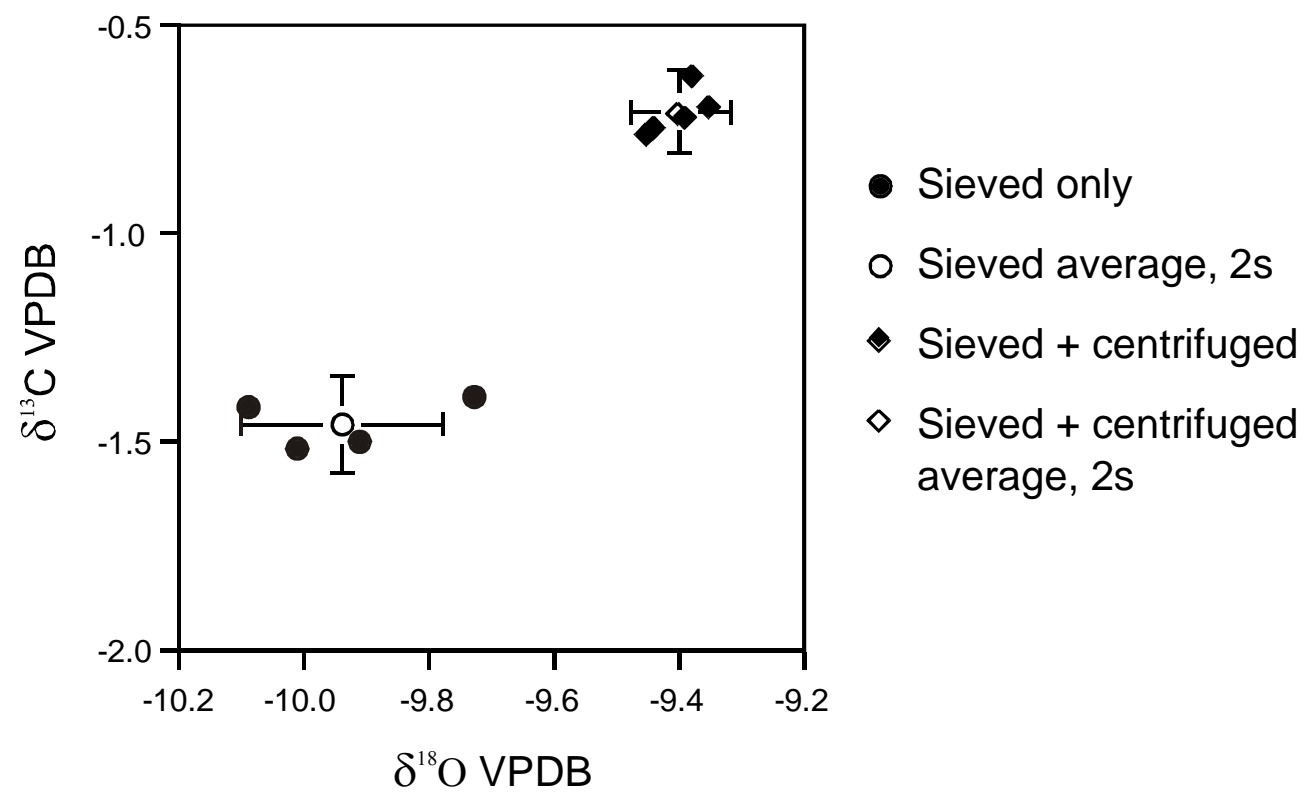

Figure 6. Sieved vs. sieved+centrifuged mud from $00-1 D$, core catcher 37 (28\% calcite, $60 \%$ quartz, $0 \%$ aragonite). 
The average $\delta^{18} \mathrm{O}$ and $\delta^{13} \mathrm{C}$ for the five subsamples did not overlap at $\pm 2 \sigma$ among the treatments. The average $\delta^{18} \mathrm{O}$ in the first 5-minute-centrifuge treatment for 00-1D13 cc was higher (by $0.3 \%$ ) and $\delta^{13} \mathrm{C}$ was lower (by $0.4 \%$ ) compared to the untreated samples. Subsamples subjected to the second 5-minute treatment showed further increases in $\delta^{18} \mathrm{O}$ (by $0.2 \%$ ) and increased ${ }^{13} \mathrm{C}$ (by $0.4 \%$ ). The centrifuged samples for 00-1D $37 \mathrm{cc}$ showed higher $\delta^{18} \mathrm{O}$ (by $0.5 \%$ ) and $\delta^{13} \mathrm{C}$ (by $0.7 \%$ ) than the untreated samples.

Based on these results, plus preliminary X-ray diffraction analyses, we conclude that analyzing untreated (sieved but not centrifuged) sediment is the most straight-forward approach. X-ray diffraction analysis of the centrifuged subsamples from 00-1D-13 cc showed no significant difference in the mineralogical composition of the sediment. Apparently, different grain sizes have slightly different isotopic ratios. This may reflect differences in allogenic verses endogenic carbonate fractions. In addition, the variability among subsamples did not improve with successive treatments. Considering the lack of a clear advantage of pretreating the sediment prior to isotope analyses, and given the effort required to perform the pretreatment, we suggest that future analyses be based on sieved, but not centrifuged marl.

\section{References cited}

Bright, J., Forester, R., and Kaufman, D.S., 2005, 0stracode analysis for cores BL96-1 and BL96-2 from Bear Lake, Utah and Idaho: U.S. Geological Survey Open-file Report 2005-1227, 13p. 